\title{
Predictors associated with HIV/AIDS patients dropout from antiretroviral therapy at Mettu Karl Hospital, southwest Ethiopia
}

\author{
Melaku Tadege* (i)
}

\begin{abstract}
Objective: The aim of this study was to determine the major risk factors of antiretroviral therapy dropout. The retrospective cohort research design was applied. 1512 HIV patients were included from Mettu Karl Hospital in Illubabor Zone, southwest part of Ethiopia from September 2005 to January 2018. Kaplan-Meier comparison and log-logistic regression accelerated failure time model were used.

Results: From the log-logistic regression result, the risk of dropout for patients with primary education status was $10.58 \%$ greater as compared to illiterate $(p<0.0110)$. The probability of dropout for patients with marital status separated was about $16.82 \%$ higher than those patients with marital status divorced ( $p<0.0070)$. Being merchant, farmer and daily labour had a greater risk of dropout as compared to a housewife. Most of the HIV/AIDS patients on ART were dropout in a short period due to patients separated marital status, primary education, CD4, being merchants, farmer and daily labour. Investigation on the cause of antiretroviral therapy dropout from a number of AIDS clinics in the country is highly appreciated.
\end{abstract}

Keywords: AIDS, ART, Ethiopia

\section{Introduction}

HIV is the most responsible causes of mortality worldwide and the primary predictor of death in sub-Saharan Africa region. The prevalence of new infections in the area accounted for $66.6 \%$ of the world. Above $68 \%$ of adults and $90 \%$ of children infected with the disease were found in this area, and more than $76 \%$ of HIV/AIDSrelated deaths were occurred in Africa [1]. In sub-Saharan Africa more than 2.2 million people were died per year due to HIV/AIDS and related causes [2,3].

In Ethiopia, 780, 000 HIV/AIDS patients were on antiretroviral therapy [4] and around one million people are reportedly living with HIV. Of all people who have ever been reported as beginning antiretroviral treatment, 249,174 are adhering to their treatment regimen and there were 55,200 AIDS-related deaths in 2013 [5].

*Correspondence: melakutadege@yahoo.com

Department of Statistics, Injibara University, Injibara, Amhara, Ethiopia
Antiretroviral therapy dropout is a serious challenge to the success of HIV/AIDS treatment. According to the world health organization report, from all patients enrolled in HIV, the percentage of success was only $23 \%$ [6]. Antiretroviral therapy dropout negatively affects the improvement of an immunological advantage of antiretroviral therapy and increases HIV/AIDS-related mortality [7]. Dropout of patients receiving antiretroviral therapy will be the reason for drug toxicity, treatment failure due to poor adherence, and drug resistance [8-10] this directly leads to death [11-15]. $40 \%$ of all patients on antiretroviral therapy were dropout in sub-Saharan Africa [16, 17]. Of all dropout patients in the region of sub-Saharan Africa, $46 \%$ of them were died [16].

Antiretroviral therapy can reduce HIV replication and it develops the immune ability [18]. There are limited data accesses about the results of the ART in Ethiopia. In Oromia region, there were 194,370 HIV/AIDS patients and of the 115,334 were on antiretroviral therapy. Of them, only $59.3 \%$ of HIV/AIDS patients were on ART 
which was far from adequate [19]. Another investigation also explained that the rate of antiretroviral therapy failure in private health facilities in Ethiopia was $20.4 \%$ [20]. In Jimma, one out of five adults had to antiretroviral therapy dropout which is a disaster for once country which aims to minimize the effect of HIV/AIDS [21].

HIV/AIDS patients with poor antiretroviral therapy follow up outcome are at high risk of death by two times than patients with good follow up adherence [22]. Patients who have poor follow up status were at risk of death by four times than who have well-adhered patients in Addis Ababa [23]. The risk of death of poor adhered patients is five times greater than better-adhered patients [24]. The study in Ethiopia also showed that around $50 \%$ of the antiretroviral therapy dropout patients were dead [25]. HIV/AIDS Patients who dropout antiretroviral therapy will likely die in a short period of time [26]. Ethiopia is among one of the most HIV/AIDS prevalence countries globally. ART treatment has a great role to prolong the life of HIV patients but, there were a high percentage of dropouts from antiretroviral therapy which causes directly facilitate death [27-29]. A study which was conducted in the Illubabor Zone recommended that investigation on antiretroviral therapy dropout in the area is timely [30]. Therefore, the aim of this study was to determine predictors of antiretroviral therapy dropout of HIV/AIDS patients at Mettu Karl Hospital in Illubabor, Ethiopia.

\section{Main text}

\section{Study area}

This study was conducted at Mettu Karl referral Hospital which is found in Ilubabor Zone, Oromia region, southwest part of Ethiopia. This is $600 \mathrm{~km}$ far from the capital city of Ethiopia. Mettu is known for its waterfalls such as Sor fall and surrounding evergreen forest.

\section{Study design}

The study was applied a retrospective cohort study design. All patients on antiretroviral therapy from September 2005 up to January 2018 were considered in the study. Secondary data from the Hospital registry was used to retrieve data all about HIV AIDS patients on antiretroviral therapy follow up. There were 3517 patients in a given time interval. Of which a total of 1512 patients were included in the study in a given time interval depending on exclusion criteria (see Additional file 1).

\section{Variables}

The dependent variable is survival time to dropout from the ART starting from September 2005 up to January 2018. The predictor variables were sex, occupation, WHO clinical stage, marital status, baseline regimen type, age, religion, educational level, CD4 level, religion, and body weight.

\section{Exclusion criteria}

Patients with; an incomplete variable of interest, transfer out and death outcomes were excluded from inferential analysis.

\section{Survival data analysis}

Factors associated with predictors of time to dropout from ART were analyzed using Kaplan-Meier comparison and log-logistic regression AFT model. Variables with $p$ value $<0.05$ was considered statistically significant.

\section{Kaplan-Meier estimation}

The Kaplan-Meier is a nonparametric method used to estimate the survival experience. The survival experience of two or more groups of between-subjects factor can be compared for equality. It is a nonparametric estimator of the survivor function $S(t)$.

$$
\hat{S}(t)=\prod_{t_{j}<t}\left(1-\frac{d_{j}}{n_{j}}\right)
$$

where $d_{j}$, is the number of individuals who experience the event at time $t_{j}$, and, $n_{j}$ is the number of individuals.

\section{Log-logistic accelerated failure time model}

The log-logistic distribution provides the most commonly used AFT model. The log-logistic regression can exhibit a non-monotonic hazard function which increases at early times and decreases at later times. It is similar in shape to the log-normal distribution but its cumulative distribution function has a simple closed form, which becomes important computationally when fitting data with censoring. The log-logistic survival and hazard function for a $\log$-linear model with no covariates $(\log T=\mu+\delta \varepsilon)$ are;

$$
\begin{aligned}
& \mathrm{S}(\mathrm{t})=\frac{1}{1+\mathrm{e}^{\theta} \mathrm{t}^{\gamma}} \\
& \mathrm{H}(\mathrm{t})=\frac{\mathrm{e}^{\theta} \gamma \mathrm{t}^{\gamma-1}}{1+\mathrm{e}^{\theta \mathrm{t}^{\gamma}}}
\end{aligned}
$$

where $\theta=\frac{-\mu}{\sigma}$ and $\gamma=\frac{1}{\sigma}$ are unknown parameters.

\section{Results}

There were 1512 patients in the cohort study out of which 243 (16.1\%) were LTFU. From the total of HIV/ AIDS patients, 933 (61.7\%) of them were female and 579 (38.3\%) were male. The majority of patients 817 (54\%) of them were married. From all, 1109 (73.3\%) of them were Christians others were Muslim. On the subject of 
education, $663(43.8 \%)$ of them were primary education complete, $338(22.4 \%)$ of them were secondary education complete, $267(17.7 \%)$ of them were unable to read and write (illiterate), 244 (16.1\%) were above secondary education level. Majority of patients 459 (30.4\%) were merchants. Of all patients, $520(34.4 \%)$ were started ART at WHO clinical stage three. On the regimen type, there were 120 (7.9\%), 488 (32.3\%), 493 (32.6\%) and $411(27.2 \%)$ patients who took AZT-3TC-EFV, D4t-3TC-NVP, D4t3TC-EFV and AZT-3TC-NVP medication type respectively. The average age of patients was 33 years and the mean follow up time of patients were 6 years (Table 1).

From the Chi square test result, dropout was significantly associated with WHO clinical stage (p value $=0.018)$ and marital status $(p$-value $=0.007)$ (see Additional file 2).

\section{Kaplan-Meier survival estimates}

The Kaplan-Meier graph showed that the survival ability of patients marital status married is less than patients with never married (see Additional file 3). From the Kaplan-Meier, log-rank test in Table 2 shows that the survival experience of patients related with occupation and original regimen type status had a significant difference on time to ART dropout at $5 \%$ of a significant level.

\section{Model selection}

The study used the AIC criterion to compare different models. For each model, the value is computed as AIC $=-2 \log$ (likelihood) $+2(p+k)$. Based on the following statistics value of the AIC/BIC criteria parametric model with log-logistic was preferable for modelling since the smallest value is preferable (see Additional file 4).

From the log-logistic regression model; when a CD4 level added by one unit, the risk of dropout increased by $0.05 \% \quad(\mathrm{AHR}=1.0005)$. Likewise, a unit change of weight could accelerate time to dropout by $0.31 \%$ $(\mathrm{AHR}=1.0031)$. The risk of dropout of patients with married marital status was $9.8 \%$ greater as compared with divorced. Patients ART dropout with separated marital status were at risk as compared to married by $16.82 \%$. The probability of ART dropout with primary education level was $10.58 \%$ greater than the illiterate patients. The risks of dropout of patients with daily labour were $87.44 \%$ greater than that of housewife. Similarly, the risks to dropout of being farmer were $82.73 \%$ as compared to housewife. Being dropout from ART with government worker was increased by $73.72 \%$ as compared to a housewife $(\mathrm{p}<0.001)$. Being a merchant also had a negative impact on dropout as compared to housewife. Patients who took D4t-3TC-EFV medication type had a greater
Table 1 Descriptive analysis of variables

\begin{tabular}{|c|c|c|}
\hline$N=1512$ & Number of events & (\%) \\
\hline \multicolumn{3}{|l|}{ Outcome } \\
\hline Number of dropout & 243 & 16.1 \\
\hline Number of censored & 1269 & 83.9 \\
\hline \multicolumn{3}{|l|}{ Sex } \\
\hline Female & 933 & 61.7 \\
\hline Male & 579 & 38.3 \\
\hline \multicolumn{3}{|l|}{ Marital status } \\
\hline Divorced & 188 & 12.4 \\
\hline Married & 817 & 54.0 \\
\hline Separated & 154 & 10.2 \\
\hline Widow & 176 & 11.6 \\
\hline Never married & 177 & 11.7 \\
\hline \multicolumn{3}{|l|}{ Educational level } \\
\hline Illiterate & 267 & 17.7 \\
\hline Primary school & 663 & 43.8 \\
\hline Secondary school & 338 & 22.4 \\
\hline Above secondary & 244 & 16.1 \\
\hline \multicolumn{3}{|l|}{ Religion } \\
\hline Christian & 1109 & 73.3 \\
\hline Muslim & 403 & 26.7 \\
\hline \multicolumn{3}{|l|}{ WHO clinical stage } \\
\hline Stage I & 475 & 31.4 \\
\hline Stage II & 352 & 23.3 \\
\hline Stage III & 520 & 34.4 \\
\hline Stage IV & 165 & 10.9 \\
\hline \multicolumn{3}{|l|}{ Original regimen } \\
\hline D4t-3TC-NVP & 488 & 32.3 \\
\hline D4t-3TC-EFV & 493 & 32.6 \\
\hline AZT-3TC-NVP & 411 & 27.2 \\
\hline AZT-3TC-EFV & 120 & 7.9 \\
\hline \multicolumn{3}{|l|}{ Occupation } \\
\hline Housewife & 344 & 22.8 \\
\hline Daily labour & 296 & 19.6 \\
\hline Farmer & 189 & 12.5 \\
\hline Government worker & 224 & 14.8 \\
\hline Merchant & 459 & 30.4 \\
\hline
\end{tabular}

risk of dropout as compared to patients who took D4t3TC-NVP by $84.23 \%$ (Table 3 ).

\section{Discussion}

In this survival retrospective cohort study, there were 243 dropouts from 1512 patients, yielding antiretroviral therapy dropout prevalence were 17/100 patients. In Gambia, only $17.2 \%$ dropout was observed [31]. Another study in Nigeria stated that there were $74.9 \%$ had been ART dropout which is greater than this investigation [32]. A study which found in sub-Saharan Africa stated that 
Table 2 Kaplan Meier long rank test result

\begin{tabular}{|c|c|c|c|c|c|c|c|}
\hline \multirow[t]{3}{*}{ Variables } & \multicolumn{3}{|c|}{ Mean estimate } & \multicolumn{3}{|c|}{ Median estimate } & \multirow[t]{3}{*}{ p } \\
\hline & \multirow[t]{2}{*}{ Estimate } & \multicolumn{2}{|l|}{$95 \% \mathrm{Cl}$} & \multirow[t]{2}{*}{ Estimate } & \multicolumn{2}{|l|}{$95 \% \mathrm{Cl}$} & \\
\hline & & $\mathrm{LCl}$ & $\mathrm{UCI}$ & & $\mathrm{LCl}$ & $\mathrm{UCI}$ & \\
\hline \multicolumn{8}{|l|}{ Sex } \\
\hline Female & 182.905 & 133.502 & 232.308 & 135.000 & 132.501 & 137.499 & 0.0889 \\
\hline Male & 131.761 & 119.924 & 143.597 & 131.000 & 124.685 & 137.315 & \\
\hline \multicolumn{8}{|l|}{ Marital } \\
\hline Divorced & 116.161 & 110.373 & 121.948 & 126.000 & 114.974 & 137.026 & 0.0001 \\
\hline Married & 148.991 & 131.994 & 165.987 & 135.000 & 121.870 & 148.130 & \\
\hline Separated & 140.209 & 134.111 & 146.308 & 149.000 & 128.970 & 169.030 & \\
\hline Widow & 117.070 & 108.881 & 125.258 & 124.000 & 112.716 & 135.284 & \\
\hline Never married & 171.348 & 104.636 & 238.061 & 130.000 & 121.385 & 138.615 & \\
\hline \multicolumn{8}{|l|}{ Education } \\
\hline Illiterate & 214.268 & 165.411 & 263.126 & 133.000 & 124.420 & 141.580 & 0.1716 \\
\hline Primary school & 137.598 & 127.585 & 147.610 & 135.000 & 129.390 & 140.610 & \\
\hline Secondary school & 151.528 & 135.514 & 167.542 & 132.000 & 128.993 & 135.007 & \\
\hline Above secondary & 126.392 & 117.717 & 135.068 & 130.000 & 117.280 & 142.720 & \\
\hline \multicolumn{8}{|l|}{ Religion } \\
\hline Christian & 160.112 & 124.299 & 195.926 & 132.000 & 127.944 & 136.056 & 0.0694 \\
\hline Muslim & 150.494 & 132.746 & 168.241 & 156.000 & 123.592 & 188.408 & \\
\hline \multicolumn{8}{|l|}{ Occupation } \\
\hline Housewife & 233.275 & 168.920 & 297.630 & 149.000 & 133.260 & 164.740 & 0.0001 \\
\hline Daily labour & 137.090 & 117.988 & 156.192 & 130.000 & 120.881 & 139.119 & \\
\hline Farmer & 122.867 & 116.163 & 129.571 & 138.000 & 110.609 & 165.391 & \\
\hline Government worker & 117.358 & 109.166 & 125.550 & 118.000 & 113.796 & 122.204 & \\
\hline Merchant & 125.597 & 119.114 & 132.080 & 129.000 & 122.795 & 135.205 & \\
\hline \multicolumn{8}{|l|}{ WHO clinical stage } \\
\hline Stage I & 134.390 & 128.543 & 140.238 & & & & 0.8367 \\
\hline Stage II & 130.374 & 123.499 & 137.250 & 138.000 & 115.751 & 160.249 & \\
\hline Stage III & 165.794 & 125.912 & 205.675 & 134.000 & 131.714 & 136.286 & \\
\hline Stage IV & 144.512 & 120.156 & 168.868 & 133.000 & 127.310 & 138.690 & \\
\hline \multicolumn{8}{|l|}{ Regimen type } \\
\hline D4t-3TC-NVP & 209.679 & 156.318 & 263.041 & 134.000 & 129.245 & 138.755 & 0.0001 \\
\hline D4t-3TC-EFV & 117.646 & 111.596 & 123.696 & 127.000 & 118.607 & 135.393 & \\
\hline AZT-3TC-NVP & 134.049 & 129.517 & 138.581 & 135.000 & 129.151 & 140.849 & \\
\hline AZT-3TC-EFV & 125.931 & 117.382 & 134.481 & 123.000 & 113.594 & 132.406 & \\
\hline
\end{tabular}

this percentage will vary from 5.7 to $28.9 \%$ [33]. A study which was conducted in the region also stated that the percentage of patients dropout was estimated to be up to $31 \%$ [34]. The average age of all patients was 33 which is the most productive age group, another study also in Zambia same echo shows that the median age were 34 [35]. Other studies across the country also statement between 31 and 33 [27, 36, 37], which is almost consistent with this study. Even though many manuscript papers stated that age was as a significant factor for antiretroviral therapy dropout, this study explained that age was not a significant impact on antiretroviral therapy dropout.
This is inconsistent with findings from other studies [38]. Unlike other studies, weight and WHO clinical stage were not a responsible cause of antiretroviral therapy dropout [39-44]. Patients with higher CD4 level have a greater risk of dropout [AHR $=1.0005$ (1.0003-1.0007)], which is directly related with the study in the UK [45] and Hospital of Bergamo cohorts [46], where dropout was related with a higher CD4 count level. Another study in French found that patients with higher CD4 count have increased the risk of antiretroviral therapy dropout $[35,47]$. This study stated that sex was not a responsible factor for loss from treatment, but another study in 
Table 3 Log-logistic AFT model result

\begin{tabular}{|c|c|c|c|c|}
\hline \multirow{2}{*}{$\begin{array}{l}\text { Model } \\
\text { Age }\end{array}$} & \multirow{2}{*}{$\begin{array}{l}\text { AHR } \\
1.0034\end{array}$} & \multirow{2}{*}{$\begin{array}{l}\mathbf{p} \\
0.0630\end{array}$} & \multicolumn{2}{|c|}{$\begin{array}{l}95 \% \text { confidence } \\
\text { interval }\end{array}$} \\
\hline & & & 0.9998 & 1.0070 \\
\hline \multicolumn{5}{|l|}{ Marital status } \\
\hline \multicolumn{5}{|l|}{ Divorced (ref) } \\
\hline Married & 1.0980 & 0.0390 & 1.0049 & 1.1999 \\
\hline Separated & 1.1682 & 0.0070 & 1.0444 & 1.3067 \\
\hline Widow & 0.9323 & 0.2000 & 0.8376 & 1.0377 \\
\hline Never married & 1.0987 & 0.1030 & 0.9812 & 1.2302 \\
\hline \multicolumn{5}{|l|}{ Education } \\
\hline \multicolumn{5}{|l|}{ Illiterate (ref) } \\
\hline Primary school & 1.1058 & 0.0110 & 1.0236 & 1.1945 \\
\hline Secondary school & 1.0526 & 0.2680 & 0.9612 & 1.1527 \\
\hline Above secondary & 1.0724 & 0.2670 & 0.9480 & 1.2131 \\
\hline \multicolumn{5}{|l|}{ Occupation } \\
\hline \multicolumn{5}{|l|}{ Housewife (ref) } \\
\hline Daily labour & 0.8744 & 0.0150 & 0.7848 & 0.9743 \\
\hline Farmer & 0.8273 & 0.0010 & 0.7413 & 0.9233 \\
\hline Government worker & 0.7372 & 0.0001 & 0.6709 & 0.8100 \\
\hline Merchant & 0.8293 & 0.0001 & 0.7656 & 0.8984 \\
\hline CD4 & 1.0005 & 0.0001 & 1.0003 & 1.0007 \\
\hline Weight & 1.0031 & 0.0890 & 0.9995 & 1.0066 \\
\hline \multicolumn{5}{|l|}{ Original regimen } \\
\hline \multicolumn{5}{|l|}{ D4t-3TC-NVP (ref) } \\
\hline D4t-3TC-EFV & 0.8423 & 0.0001 & 0.7811 & 0.9083 \\
\hline AZT-3TC-NVP & 1.0467 & 0.1990 & 0.9762 & 1.1222 \\
\hline AZT-3TC-EFV & 0.9707 & 0.5720 & 0.8757 & 1.0760 \\
\hline
\end{tabular}

AHR, adjusted hazard ratio; $p, p$ value; Ref, reference category

Ethiopia stated that being male was one of the predictors for antiretroviral therapy dropout [48]. Likewise, no association was found between sex and loss from treatment [49-51], but not other studies [52-54]. The difference may arise because of sample size, study design and follow up time difference. Some previous studies suggest that marital status can predict dropout among ART initiators [55-57]. In this data, the patient's initially receiving D4t-3TC-EFV regimens had decreased risk of dropout as compared with patients who took D4t-3TC-NVP medication type. But the regimen type AZT was not a significant predictor as compared to D4T based which is consistent with another study [57]. This study will serve as resource material for researchers, managers, policymakers. Additionally, the study will be used as a baseline for further researchers.

\section{Conclusion}

In conclusion, HIV/AIDS patients on antiretroviral therapy were dropout in a short period due to patients marital status married and separated, primary education level, high level of CD4 count, being merchants, farmer and daily labour. Investigation on the cause of antiretroviral therapy dropout from a number of HIV/AIDS clinics in the country is highly appreciated.

\section{Limitations}

There were a lot of patients with incomplete records which were excluded from this investigation; this may affect the conclusion of the study.

\section{Additional files}

\section{Additional file 1: Figure S1. Sample selection extraction. There were 3517 patients in Mettu Karl Hospital in the time period, But only 1512 patients were included because of variable of interest (patients with lack of adequate information about their follow up were exclude). \\ Additional file 2. Chi-square test result. Test of association between predictor variables and survival status. \\ Additional file 3. Kaplan-Meier survival estimates. The graphical explana- tion of survival experience ability of patients. \\ Additional file 4. Model comparison. Model comparison means the best fit of data and model to select for conclusion.}

\section{Abbreviations}

WHO: World Health Organization; HIV: human immunodeficiency virus; AIDS: acquired immune deficiency syndrome; AFT: accelerated failure time; ART: antiretroviral therapy.

\section{Authors' contributions}

This research paper entire activity was done by MT. The author read and approved the final manuscript.

\section{Acknowledgements}

The author wishes to thank Mettu Karl Hospital workers specifically Mr. Tadele Mitiku, for his willingness and help during the entire data collection process.

\section{Competing interests}

The author declares no competing interests.

\section{Availability of data and materials}

If needed the raw data in excel format for this article is available.

\section{Consent for publication}

Not applicable.

\section{Ethics approval and consent to participate}

This study used secondary data from medical case records and patients were not contacted. The data from the case records were handled with strong responsibility and confidentiality. The study was started after ethical clearance was obtained from Mettu University research committee and permission was taken from Mettu Karl Hospital medical director to collect data from records.

Funding

There was no fund.

\section{Publisher's Note}

Springer Nature remains neutral with regard to jurisdictional claims in published maps and institutional affiliations. 
Received: 18 January 2019 Accepted: 12 April 2019

Published online: 18 April 2019

\section{References}

1. Joint United Nations Programme on HIV and AIDS and World Health Organization. AIDS Epidemic Update. Geneva: Joint United Nations Programme on HIV and AIDS; 2007. http://data.unaids.org/pub/EPISI ides/2007/2007_epiupdate_en.pdf.

2. United Nations General Assembly. Political Declaration on HIV/AIDS: intensifying our efforts to eliminate HIV/AIDS. New York, United Nations, 2011. http://www.un.org/Docs/journal/asp/ws.asp?m=A/65/L.77.

3. Global plan towards the elimination of new HIV infections among children by 2015 and keeping their mother alive-2011-2015. Geneva: UNAIDS; 2011. http://www.unaids.org/en/media/unaids/contentassets/ documents/unaidspublication/2011/20110609_JC2137_Global-PlanElimination-HIV-Children_en.pdf.

4. World health organization, HIV/AIDS, Ethiopia. http://apps.who.int/gho/ data/node.main.626.

5. Federal democratic republic of Ethiopia, Country progress report on the HIV response, 2014

6. World Health Organization. Retention in HIV Programmes Defining the Challenges and Identifying Solutions. 2011. http://apps.who.int/iris/bitst ream/10665/44878/1/9789241503686_eng.pdf.

7. Hogg RS, Heath K, Bangsberg D, Yip B, Press N, O'shaughnessy MV Montaner JS. Intermittent use of triple-combination therapy is predictive of mortality at baseline and after 1 year of follow-up. AIDS. 2002;16(7):1051-8.

8. Kaplan JE, Hanson D, Dworkin MS, Frederick T, Bertolli J, Lindegren ML, Holmberg S, Jones JL. Epidemiology of human immunodeficiency virus-associated opportunistic infections in the United States in the era of highly active antiretroviral therapy. Clin Infect Dis. 2000;30(1):S5-14.

9. Low-Beer S, Yip B, O'shaughnessy MV, Hogg RS, Montaner JS. Adherence to triple therapy and viral load response. J Acquir Immune Defic Syndr. 2000;23(4):360-1.

10. Taiwo B. Understanding transmitted HIV resistance through the experience in the USA. Int J Infect Dis. 2009;13(5):552-9.

11. Dalal RP, MacPhail C, Mahayi M, Wing J, Feldman C, Chersich MF, Venter WD. Characteristics and outcomes of adult patients lost to follow-up at an antiretroviral treatment clinic in Johannesburg, South Africa. J Acquir Immune Defic Syndr. 2008;47(1):101-7.

12. Brennan AT, Maskew M, Sanne I, Fox MP. The importance of clinic attendance in the first six months on antiretroviral treatment: a retrospective analysis at a large public sector HIV clinic in South Africa. J Int AIDS Soc. 2010;13(1):49.

13. Bygrave H, Kranzer K, Hilderbrand K, Whittall J, Jouquet G, Goemaere E, Vlahakis N, Triviño L, Makakole L, Ford N. Trends in loss to follow-up among migrant workers on antiretroviral therapy in a community cohort in Lesotho. PLoS ONE. 2010;5(10):e13198.

14. Malcolm S, Ng J, Rosen $\mathrm{R}$, Stone $\mathrm{V}$. An examination of HIV/AIDS patients who have excellent adherence to HAART. AIDS Care. 2003;15(2):251-61.

15. Murphy DA, Sarr M, Durako SJ, Moscicki A-B, Wilson CM, Muenz LR. Barriers to HAART adherence among human immunodeficiency virusinfected adolescents. Arch Pediatr Adolesc Med. 2003;157(3):249-55.

16. Brinkhof MW, Pujades-Rodriguez M, Egger M. Mortality of patients lost to follow-up in antiretroviral treatment programmes in resource-limited settings: systematic review and meta-analysis. PLoS ONE. 2009;4(6):e5790.

17. Fatti G, Meintjes G, Shea J, Eley B, Grimwood A. Improved survival and antiretroviral treatment outcomes in adults receiving community-based adherence support: 5-year results from a multicentre cohort study in South Africa. J Acquir Immune Defic Syndr. 2012;61(4):e50-8.

18. Federal HIV/AIDS Prevention and Control Office, Federal Ministry of Health. Guidelines for management of opportunistic infections and antiretroviral treatment in adolescences and adults in Ethiopia. http:// www.who.int/hiv/pub/guidelines/ethiopia_art.pdf.

19. Yassin S, Gebretekle GB. Magnitude and predictors of antiretroviral treatment failure among HIV-infected children in Fiche and Kuyu hospitals, Oromia region, Ethiopia: a retrospective cohort study. Pharmacol Res Persp. 2017;5(1):e00296.
20. Yimer YT, Yalew AW. Magnitude and predictors of anti-retroviral treatment (ART) failure in private health facilities in Addis Ababa, Ethiopia. PLoS ONE. 2015;10(5):e0126026.

21. Gesesew HA, Ward P, Woldemichael K, Mwanri L. Prevalence, trend and risk factors for antiretroviral therapy discontinuation among HIV-infected adults in Ethiopia in 2003-2015. PLoS ONE. 2017;12(6):e0179533.

22. Abebe N, Alemu K, Asfaw T, Abajobir AA. Survival status of hiv positive adults on antiretroviral treatment in Debre Markos Referral Hospital, Northwest Ethiopia: retrospective cohort study. Pan Afr Med J. 2014;17:88

23. Bedru A, Worku A. Assessment of predictors of survival in patients living with HIV/AIDS after the advent of highly active antiretroviral therapy in Addis Ababa Ethiopia [MPH thesis]. Addis Ababa University. 2009.

24. Abose G, Enkusilassie F. Survival status among patient living with HIV/ AIDS who are on art treatment in Durame and Hossana hospitals: a retrospective longitudinal study. Thesis; 2012.

25. Wubshet M, Berhane Y, Worku A, Kebede Y. Death and seeking alternative therapy largely accounted for lost to follow-up of patients on ART in northwest Ethiopia: a community tracking survey. PLoS ONE. 2013;8(3):e59197.

26. Keiser O, Tweya H, Braitstein P, Dabis F, MacPhail P, Boulle A, Nash D, Wood R, Lüthi R, Brinkhof MW. Mortality after failure of antiretroviral therapy in sub-Saharan Africa. Trop Med Int Health. 2010;15(2):251-8.

27. Alemu AW, Sebastián MS. Determinants of survival in adult HIV patients on antiretroviral therapy in Oromiyaa, Ethiopia. Glob Health Action. 2010;3(1):5398.

28. Teklu AM, Nega A, Mamuye AT, Sitotaw Y, Kassa D, Mesfin G, Belayihun B, Medhin G, Yirdaw K. Factors associated with mortality of TB/HIV coinfected patients in Ethiopia. Ethiop J Health Sci. 2017;27(1):29-38.

29. Bitew S, Mekonen A, Assegid M. Predictors on mortality of human immunodeficiency virus infected children after initiation of antiretroviral treatment in Wolaita zone health facilities, Ethiopia: retrospective cohort study. J AIDS HIV Res. 2017;9(4):89-97.

30. Tadege M. Time to death predictors of HIV/AIDS infected patients on antiretroviral therapy in Ethiopia. BMC Res Notes. 2018;11(1):761.

31. Togun T, Peterson I, Jaffar S, Oko F, Okomo U, Peterson K, Jaye A. Pretreatment mortality and loss-to-follow-up in HIV-1, HIV-2 and HIV-1/HIV-2 dually infected patients eligible for antiretroviral therapy in The Gambia, West Africa. AIDS Res Ther. 2011;8(1):24.

32. Agolory SG, Auld AF, Odafe S, Shiraishi RW, Dokubo EK, Swaminathan M, Dalhatu I, Onotu D, Abiri O, Debem H. High rates of loss to followup during the first year of pre-antiretroviral therapy for HIV patients at sites providing pre-ART care in Nigeria, 2004-2012. PLoS ONE. 2017;12(9):e0183823.

33. Brinkhof MW, Spycher BD, Yiannoutsos C, Weigel R, Wood R, Messou E, Boulle A, Egger M, Sterne JA. AIDS leDtE: adjusting mortality for loss to follow-up: analysis of five ART programmes in sub-Saharan Africa. PLoS ONE. 2010;5(11):e14149.

34. Rosen S, Fox MP, Gill CJ. Patient retention in antiretroviral therapy programs in sub-Saharan Africa: a systematic review. PLoS Med. 2007;4(10):e298.

35. Li MS, Musonda P, Gartland M, Mulenga PL, Mwango A, Stringer JS, Chi $\mathrm{BH}$. Predictors of patient attrition according to different definitions for loss to follow-up: a comparative analysis from Lusaka, Zambia. J Acquir Immune Defic Syndr. 2013;63(3):e116.

36. Amanzi P, Michelo C, Simoonga C, Dambe R, Chongwe G. Survival of people on antiretroviral treatment in Zambia: a retrospective cohort analysis of HIV clients on ART. Pan Afr Med J. 2016;24:144.

37. Sieleunou I, Souleymanou M, Schönenberger AM, Menten J, Boelaert M. Determinants of survival in AIDS patients on antiretroviral therapy in a rural centre in the Far-North Province, Cameroon. Trop Med Int Health. 2009;14(1):36-43.

38. Fox MP, Shearer K, Maskew M, Meyer-Rath G, Clouse K, Sanne I. Attrition through multiple stages of pre-treatment and ART HIV care in South Africa. PLoS ONE. 2014;9(10):e110252.

39. Lawn SD, Harries AD, Anglaret X, Myer L, Wood R. Early mortality among adults accessing antiretroviral treatment programmes in sub-Saharan Africa. AIDS (London, England). 2008;22(15):1897-908.

40. Feldacker C, Johnson D, Hosseinipour M, Phiri S, Tweya H. Who starts? Factors associated with starting antiretroviral therapy among eligible patients in two, public HIV clinics in Lilongwe, Malawi. PLOS ONE. 2012:7(11):e50871. 
41. IeDEA T. Immunodeficiency at the start of combination antiretroviral therapy in low-, middle-and high-income countries. J Acquir Immune Defic Syndr. 2014;65(1):8.

42. Hassan AS, Fielding KL, Thuo NM, Nabwera HM, Sanders EJ, Berkley JA. Early loss to follow-up of recently diagnosed HIV-infected adults from routine pre-ART care in a rural district hospital in Kenya: a cohort study. Trop Med Int Health. 2012;17(1):82-93.

43. Ingle $S$, Margaret M, Uebel K, Timmerman V, Kotze E, Bachmann M, Sterne JA, Egger M, Fairall L. Outcomes in patients waiting for antiretroviral treatment in the Free State Province, South Africa: prospective linkage study. AIDS (London, England). 2010;24(17):2717.

44. Mulissa Z, Jerene D, Lindtjørn B. Patients present earlier and survival has improved, but pre-ART attrition is high in a six-year HIV cohort data from Ethiopia. PLoS ONE. 2010;5(10):e13268.

45. Hill T, Bansi L, Sabin C, Phillips A, Dunn D, Anderson J, Easterbrook P, Fisher M, Gazzard B, Gilson R. Data linkage reduces loss to follow-up in an observational HIV cohort study. J Clin Epidemiol. 2010;63(10):1101-9.

46. Arici C, Ripamonti D, Maggiolo F, Rizzi M, Finazzi M, Pezzotti P, Suter F. Factors associated with the failure of HIV-positive persons to return for scheduled medical visits. HIV Clin Trials. 2002;3(1):52-7.

47. Ndiaye B, Ould-Kaci K, Salleron J, Bataille P, Bonnevie F, Choisy P, Cochonat K, Fontier C, Guerroumi H, Ajana F. Incidence rate and risk factors for loss to follow-up in HIV-infected patients from five French clinical centres in Northern France-January 1997 to December 2006. Antivir Ther. 2009;14(4):567-75.

48. Mekuria LA, Prins JM, Yalew AW, Sprangers MA, Nieuwkerk PT. Retention in HIV care and predictors of attrition from care among HIV-infected adults receiving combination anti-retroviral therapy in Addis Ababa. PLoS ONE. 2015;10(6):e0130649.

49. Li L, Lee SJ, Wen Y, Lin C, Wan D, Jiraphongsa C. Antiretroviral therapy adherence among patients living with HIV/AIDS in Thailand. Nurs Health Sci. 2010;12(2):212-20.
50. Pinheiro C, Carvalho-Leite J, Drachler M, Silveira V Factors associated with adherence to antiretroviral therapy in HIV/AIDS patients: a cross-sectional study in Southern Brazil. Braz J Med Biol Res. 2002;35(10):1173-81.

51. Collazos J, Asensi V, Cartón JA. Adherencia GEpeEMdl: Sex differences in the clinical, immunological and virological parameters of HIV-infected patients treated with HAART. Aids. 2007;21(7):835-43.

52. Mehta S, Moore RD, Graham NM. Potential factors affecting adherence with HIV therapy. Aids. 1997;11(14):1665-70.

53. Cahn P, Vibhagool A, Schechter M, Soto-Ramirez L, Carosi G, Smaill F, Jordan JC, Pharo CE, Thomas NE, Steel HM. Predictors of adherence and virologic outcome in HIV-infected patients treated with abacavir-or indinavir-based triple combination HAART also containing lamivudine/ zidovudine. Curr Med Res Opin. 2004;20(7):1115-23.

54. Bonolo P, César CC, Acúrcio FA, Graças BC, Pádua CA, Álvares J, Campos LN, Carmo RA, Guimarães MD. Non-adherence among patients initiating antiretroviral therapy: a challenge for health professionals in Brazil. Aids. 2005; 19:S5-13.

55. Meloni ST, Chang C, Chaplin B, Rawizza H, Jolayemi O, Banigbe B, Okonkwo P, Kanki P. Time-dependent predictors of loss to follow-up in a large HIV treatment cohort in Nigeria. In: Open forum infectious diseases. Oxford University Press; 2014.

56. Berheto TM, Haile DB, Mohammed S. Predictors of loss to follow-up in patients living with HIV/AIDS after initiation of antiretroviral therapy. N Am J Med Sci. 2014;6(9):453.

57. Asiimwe SB, Kanyesigye M, Bwana B, Okello S, Muyindike W. Predictors of dropout from care among HIV-infected patients initiating antiretroviral therapy at a public sector HIV treatment clinic in sub-Saharan Africa. BMC Infect Dis. 2015;16(1):43
Ready to submit your research? Choose BMC and benefit from:

- fast, convenient online submission

- thorough peer review by experienced researchers in your field

- rapid publication on acceptance

- support for research data, including large and complex data types

- gold Open Access which fosters wider collaboration and increased citations

- maximum visibility for your research: over $100 \mathrm{M}$ website views per year

At $\mathrm{BMC}$, research is always in progress.

Learn more biomedcentral.com/submissions 